\title{
aniki
}

Revista Portuguesa da Imagem em Movimento

Portuguese Journal of the Moving Image

\section{Editorial v7n2}

Os Editores

Dois anos depois, quatro números lançados, o trabalho deste Conselho Editorial está concluído. Nestes dois anos, muito mudou. A Aniki, de forma mais visível ou consciente, também viveu essas mudanças, mais particularmente em Portugal, no Brasil e em França, espaços onde vivem e trabalham os membros do Conselho Editorial, mas também noutras latitudes. Fomos vivendo com entusiasmo e preocupação muitas das mudanças políticas e sociais ocorridas ao longo dos últimos anos, mas há uma situação concreta que nos vem sensibilizando de forma particular.

No meio mediático atual, dominado pela pandemia e pela consequente crise social e financeira que nos torna mais inseguros, a Cinemateca Brasileira está ameaçada. Questionada na sua missão, instrumentalizada por interesses ideológicos, a entidade que guarda o maior acervo fílmico da América Latina, que zela pela memória do cinema e do audiovisual brasileiro desde 1949 (então como Filmoteca do Museu de Arte Moderna de São Paulo), que sobreviveu à Ditadura Militar, a quatro incêndios e a várias crises, está perante um cenário de extinção iminente.

Neste momento delicado, o Conselho Editorial da Aniki não pode deixar de manifestar a sua solidariedade para com dezenas de funcionários e com a própria instituição, celebrando a memória de diversos intelectuais e artistas, como Paulo Emílio Sales Gomes, Décio de Almeida Prado, Antonio Candido de Mello e Souza ou ainda Maria Rita Galvão, que ao longo das décadas transformaram a instituição numa referência entre os arquivos fílmicos e os centros de documentação internacionais.

O património que a Cinemateca Brasileira hoje preserva não é apenas cinematográfico, fazendo parte da história e da memória do próprio país. A sua perda, ou incúria negligente, será irreparável. A Aniki, enquanto revista dedicada à investigação do património e produção audiovisual não pode deixar de se manifestar publicamente contra tal eventualidade que afetará o trabalho de investigação e conhecimento de uma parte importantíssima da história do cinema. 
Este número da Aniki, o décimo quarto, só existe devido ao generoso trabalho de dezenas de pessoas no decurso dos últimos meses, nomeadamente os autores, que continuam a confiar à nossa revista o seu trabalho, e os revisores, que partilham connosco a responsabilidade de manter a qualidade científica da Aniki.

O trabalho de preparação deste número começou em junho de 2019, com o convite do Conselho Editorial da Aniki a Manuela Penafria (Universidade da Beira Interior, Portugal), Eduardo Tulio Baggio (Universidade Estadual do Paraná, Brasil) e André Rui Graça (Universidade de Coimbra, Portugal) para coordenarem um Dossiê Temático, que decidiram intitular de "Teoria dos Cineastas: uma abordagem para o estudo do cinema", convidando à problematização deste ângulo de análise/ teórico-analítico, tanto como enquadramento metodológico como enquanto abordagem às obras de cinema e ao labor fílmico, num campo que se encontra ainda em fase de reflexão e consolidação.

A chamada para artigos, lançada em agosto de 2019, esteve aberta até 15 de dezembro desse ano. Para esta edição recebemos 32 textos para as secções sujeitas a revisão cega por pares: foram submetidas 14 propostas para o Dossiê Temático, seis das quais foram aceites; para a secção Ensaios foram submetidas 18 propostas, sendo que três foram aprovadas para publicação neste número.

Nas restantes secções, que não estão sujeitas ao processo de revisão cega, o controlo da qualidade dos textos é assegurado pelos respectivos editores residentes. Destacamos, na secção Entrevistas, uma entrevista exclusiva ao mineiro Affonso Uchôa, um dos cineastas brasileiros mais interessantes da sua geração, uma presença que se afirmou no panorama do cinema brasileiro e internacional, apesar das adversas condições de produção, e que urge ver e ouvir para compreender um país devastado por uma regressão política e social sem precedentes.

Também queremos deixar o nosso agradecimento particular à Raquel Morais, assistente editorial da Aniki durante estes dois anos, que muito nos ajudou e simplificou a tarefa de edição dos quatro números sob nossa responsabilidade.

Por fim, agradecemos aos nossos leitores, que continuam a justificar todo este projeto, e que esperamos que continuem a acompanhar a revista no futuro.

Com o nosso voto de até breve.

Paulo Cunha, Sofia Sampaio, Lúcia Ramos Monteiro, Jorge Palinhos e Mickaël Robert-Gonçalves. 